\title{
Preparation of Biologically Active Recombinant Buffalo Follicle Stimulating Hormone (rbuFSH) from Buffalo pituitaries
}

\author{
A. M.Hammam*, A. N. Mohamed ${ }^{*}$ and M.M. Ahmed ${ }^{* *}$ A. M. G. Kandeil ${ }^{* * *}$ \\ *Department of Animal Reproduction and A.I., Veterinary Research Division \\ and $^{* *}$ Department of Water Pollution, Environment Research Division and Department \\ of Animal Reproduction, Veterinary Research Division, National Research Centre, \\ Cairo, Egypt.
}

\begin{abstract}
D UE to the immunogenic differences in the FSH- $\beta$ subunits among animal species and the need for preparing specific gonadotropic hormones specific for buffaloes, the present work was aimed to prepare recombinant buffalo follicle stimulating hormone for using in improving the fertility of Egyptian buffaloes. Production of recombinant buffalo follicle stimulating hormone (rbuFSH) in E.coli by using recent biotechnological tools .Buffalo anterior pituitaries were collected from slaughtered buffaloes, the buffalo common $\alpha$-subunit and FSH $\beta$-subunit cDNAs was cloned and expressed to produce recombinant FSH from buffalo species in vitro. The RNAs extracted from buffalo pituitary glands will be reverse-transcribed and amplified by PCR and RT-PCR. The cDNAs corresponding to both subunits of buffalo hormones was cloned into the expression vector E.coli cells (DH5 $\alpha$ ) and pGEMT-Easy vector and transfected into pET 28a, pET 15b cells or pCR2.1-TOPO vector. Subcloning of the different subunits was carried out in pET vectors. Expression of genes was determined in the transfected cells by Northern and Western blot analysis. Recombinant buffalo FSH secreted in culture media was characterized by an in vitro bioassay. The recombinant products were injected to immature female rats compared to PMSG(standard) to stimulate ovarian growth and inducing of multiple follicles. The results revealed that the possibility of producing recombinant buff. FSH in vitro which are possessing efficient biological activity,stimulated the ovarian activity of immature female rats compared with standard PMSG hormone, which can be applied in buffalo-cows for improvement of reproductive efficiency .
\end{abstract}

Keywords: Recombinant FSH, Buffalo, Pituitary glands- cDNA, Cloning, RT-PCR.

\section{Introduction}

Buffaloes are one of the main sources of meat and milk in Egypt and contributes $70 \%$ of milk and $40 \%$ of meat production [1]. Globally it counted about 188.31 million buffalo according to FAO, 2010[2], 97\% in Asia, 2\% in Africa , and $0.2 \%$ in Europe . Buffaloes are raring under harsh environment and suffering from different reproductive problems either due to genetic and/ or environmental factors (malnutrition, heat stress, bad hygiene, infection and pollution). The reproductive process in buffaloes is very slow, represented in prolonged postpartum acyclicity and anoestrus which are considered major sources of economic losses to buffalo breeders $[3,4]$. Delayed onset of post-partum ovarian activity have been recorded in lactating buffaloes [5], which may be due to suppressed pituitary responsiveness to exogenous GnRH challenge in post-partum buffaloes [6]. Also long anestrous periods due to cessation of cyclic activity for 3 weeks or more and prolonged luteal activity for 28 days or more [7]. On the other hand buffalo's ovary has a smaller population of recruitable follicles at any given time than cow's ovary [8].

Induction of multiple ovulations (superovulation) by hormonal treatment was one of the tools previously used to improve fertility and reproductive efficiency of buffaloes through injection of gonadotropic hormones preparations, such as pituitary gonadotropin (FSH-P), porcine follicle stimulating hormone (PFSH), equine chorionic gonadotropin (eCG) or pregnant mare serum gonadotropin (PMSG) [9], in order to trigger the development of more than one dominant follicle. FSH has conventionally been

Corresponding Author : Abdel Mohsen Mohamed Hammam, e-mail:hammam956@gmail.com

Mobile: 01155911033

DOI:10.21608/ejvs.2018.4189.1040

C2017 National Information and Documentation Centre (NIDOC) 
derived from pituitary tissue, despite concerns that include contamination with other pituitary hormones such as LH $[10,11]$, batch-to-batch variation $[10,12]$, and potential to spread diseasecausing agents $[10,11]$. Initially, recombinant gonadotropins such as FSH were produced as two separate subunits oligomerized after synthesis $[13$,$] . Later efforts included studies aimed at the$ expression of constructs that yielded both protein subunits fused together, which quickly became the standard production method because it required fewer steps during synthesis and purification [14].

The next focus of recombinant gonadotropin research included efforts to modify the subunits to yield increased in vivo biological half-life (and therefore decrease the number of doses required for adequate superovulation). By engineering up to four extra N-linked glycosylation consensus sites into the $\alpha$ - subunit, retention time was enhanced $[15,16]$. Increased retention time has also been achieved by adding a section of DNA that codes for a highly glycosylated protein to one terminus of the protein $[17,18]$. Acidic residues tend to have reduced glomerular filtration in the kidney and a protective effect within the liver $[14,18]$.

Some researchers have developed fused $\alpha$ and $\beta$ constructs that have the ability to bind to multiple gonadotropin receptors [19]. In sheep, an increase in estradiol production as a result of treatment with a dual active $\mathrm{FSH} / \mathrm{LH}$ gonadotropin was similar to a combination of individual FSH and hCO hormones, suggesting the ability of the dual gonadotropin was sufficient to activate both receptors and elicit multiple biological responses [11]. Further, the technology can be tweaked to include other gene domains such as angiogenic or steroidogenic factors [11].

Recombinant gonadotropin production from modified $\mathrm{CHO}$ cells has been similar to $\mathrm{hFSH}$, bovine (bFSH) was initially produced in $\mathrm{CHO}$ cells and found to have biological activity [20], but is no longer available in sufficient quantities for commercial purposes. Other production methods have been explored for both FSH and LH and have resulted in a biologically active protein. These methods employ the use of bacteria [21,22], viruses [23], insects [24,25], tobacco plants [26], yeast [27,28], and transgenic milk [29,30]. The use of hosts such as bacteria and yeast may provide a safer alternative to $\mathrm{CHO}$ production due to the lack of FBS utilization. Conversely, these systems do not harbor the glycosylation capabilities employed by $\mathrm{CHO}$ cells, and in some cases hyperglycosylate proteins, which may or may not have positive effects on biological activity [31].

rFSH was considered valuable for induction of superovulation in cattle and horses as an effort to harvest multiple embryos used for embryo transfer [32] .Revelli et al. [33]demonstrated that the overall FSH dose needed to achieve ovulation was significantly lower with r-FSH, whereas all the other studied variables did not significantly differ with either treatment. Therefore, the aim of the present work was to prepare specific recombinant gonadotropic hormones specially FSH and LH from native breeds of buffalo-pituitaries to be used in improvement of buffalo fertility.

\section{Material and Methods}

\section{Chemicals and biological materials:}

The buffalo pituitaries were procured from a local abattoir (Al warrak, Giza). RNA extraction kit from the pituitary gland using Qiagen. TRIreagent was purchased from Sigma Co., St. Louis, Missouri, USA. Oligo-dT primers were purchased from Biosearch technologies Co., USA. The cloning vector pGEMT-Easy was purchased from Promega Life Sciences and the bacterial expression vectors pET $28 \alpha$, pET $15 \beta$ were purchased from Novagen.

The E.coli strain DH5 $\alpha$ and BL21(DE3)pLysS were purchased from Gibco BRL and Novagen respectively. All restriction enzymes and other enzymes were purchased from New England Biolabs (NEB), Beverly, MA, USA or MBI Fermentas. PMSG was purchased fromIntervet International BV., Boxmeer-Holland.

All the other reagents were obtained from Sigma Chemical Company, USA

\section{Total RNA extraction from Buffalo Pituitary Glands}

All the glassware and plastic ware treated with $0.1 \% \mathrm{DEPC}$ (Diethyl PyroCarbonate) (Sigma) for 8-12 h, autoclaved and dried. Fresh buffalo pituitaries were removed from the skull of buffaloes within $30 \mathrm{~min}$ of slaughter. The pituitaries were cut into pieces of about $10 \mathrm{mg}$ by weighting and rinsed twice in RNase free DEPC treated water and quickly frozen in liquid nitrogen.

RNA was extracted from the pituitary gland using Qiagen RN easy kit according 
to the manufacturer protocol. Briefly, to each 0.2 grams tissue sample, $600 \mu$ of RLT and $6 \mu$ mercptoethanol was added and then homogenized using Qiagen tissue ruptor at 33,000 rpm for 40 seconds and centrifuged for 3 minutes at full speed. Then, 1 volume of $70 \%$ ethanol was added to the supernatant with pipetting and then transferred to the spin column and centrifuged at maximum speed. After washing with RW1 and PRE, the columns were transferred into new collection tubes to elute the RNA using 60 $\mu \mathrm{l}$ of RNase free water. RNA was estimated by measuring the absorbance of the eluted samples at $260 \mathrm{~nm}$ using NanoDrop2000c spectrophotometer (Thermo Scientific, Wilmington, DE, USA).The purity of purified samples was determined by calculation of $\mathrm{OD}_{260} / \mathrm{OD}_{280} \mathrm{~nm}$ ratio and the ratio was recorded.
Samples showing A260/A280 in a range of 1.8-2.0 were used for first strand cDNAsynthesis [34]

\section{Amplification of full length using RT-PCR}

Full genes of LH and FSH were amplified by RT-PCR using newly designed primers.

Reverse transcription (RT) of the extracted RNA was performed for synthesis of cDNA followed by polymerase chain reaction (PCR) of full length as one step reaction using thermal cycler.

The following reagents as showed in Table 2 were added to a micro-centrifuge tubes and mixed gently by pipetting up and down several times. For control reaction, $5 \mu$ of distilled water was added instead of sample as a negative control. The thermal profile of 2 genes was illustrated in Table 3.

TABLE 1. Primers for gonadotrophic hormones (FSH, LH, gonadotropins and TSH) forward and backword

\begin{tabular}{|c|c|c|}
\hline Name & Primer design & Ref.no. \\
\hline FSH-F-33 & 5`d ATGAAGTCCGTCCAGTTCTGC 3` & SS302219-15 \\
\hline FSH-R-33 & 5`d TTATTCTCTGCTTTCACTGAAGGAG 3` & SS302219-16 \\
\hline Gonadotropin F-33 & 5`d TCGCTCTGGCCATTTTGTCT 3` & SS302219-17 \\
\hline Gonadotropin R-33 & 5`d TTGGAGCATCTGGCTTGGAG 3’ & SS302219-18 \\
\hline LH-F-33 & 5’d ATGGAGATGTTCCAGGGACT 3’ & SS302219-21 \\
\hline LH-R-33 & 5`d TTAGAGGAAGAGGATGTCTGGG 3’ & SS302219-21 \\
\hline TSH-F-33 & 5`d ATGACTGCTACCTTCCTGATGTC 3’ & SS302219-19 \\
\hline TSH-R-33 & 5'd TTAGATAGAAAATCCCACCATATAGGA 3’ & SS302219-20 \\
\hline
\end{tabular}

TABLE 2. RT-PCR reaction contents

\begin{tabular}{lc}
\hline \multicolumn{1}{c}{ Component } & Volume/reaction $(\boldsymbol{\mu l})$ \\
\hline RNase-free water & 24 \\
5X Qiagen RT-PCR buffer & 10 \\
dNTPs $(10 \mathrm{mM}$ of each dNTP) & 2 \\
Forward primer $(10 \mu \mathrm{mol} / \mu \mathrm{l})$ & 3 \\
Reverse primer $(10 \mu \mathrm{mol} / \mu \mathrm{l})$ & 3 \\
QiagenOneStep RT-PCR enzyme mix & 2 \\
RNase inhibitor $(20 \mathrm{U} / \mu \mathrm{l})$ & 1 \\
Extracted RNA & 2 \\
Final reaction volume & 5 \\
\hline
\end{tabular}


TABLE 3. Thermal cycling conditions used for amplification of full LH and FSH genes

\begin{tabular}{lcc}
\hline \multicolumn{1}{c}{ Step } & $\begin{array}{c}\text { Temperature } \\
\left({ }^{\circ} \mathbf{C}\right)\end{array}$ & $\begin{array}{c}\text { Time } \\
(\mathbf{m i n}: \mathbf{s e c})\end{array}$ \\
\hline $\begin{array}{l}\text { Reverse transcription } \\
\text { Initial PCR activation step. }\end{array}$ & 50 & $60: 00$ \\
$\begin{array}{l}\text { Taq DNAPolymerase is activated by this heating step. Reverse transcriptase } \\
\text { is inactivated and the cDNA template is denatured. }\end{array}$ & 95 & $15: 00$ \\
Three step cycling (35 cycles) & & \\
Denaturation & & $0: 30$ \\
Annealing & 94 & $0: 30$ \\
Extension & 50 & $2: 00$ \\
Final extension step & 72 & $15: 00$ \\
\hline
\end{tabular}

According to Nolan et al.,[35]

\section{TA cloning of LH and FSH genes \\ pCR2.1-TOPO vector (TOPO TA Cloning} system, Invitrogen, USA, Cat. No. K4520-01) was used as a transfer vector in the cloning process of two genes. The plasmid (pCR2.1-TOPO vector) is supplied linearized withsingle 3 '-thymidine (T) overhangs for TA cloning. Taqpolymerase has a nontemplate-dependent terminal transferase activity that adds a single deoxyadenosine (A) to the $3^{\prime}$ ends of PCR products. The linearized vector has single, overhanging 3' deoxythymidine (T) residues. This allows LH and FSH amplicon to ligate efficiently with the vector.The TOPO cloning reaction was simply consist of $3 \mu \mathrm{l}$ fresh PCR product, $1 \mu$ l salt solution $(200 \mathrm{mMNaCl}$ and $10 \mathrm{mM} \mathrm{MgCl}_{2}$ to increase the number of transformants), $1 \mu \mathrm{l}$ TOPO vector $(10 \mathrm{ng} / \mu \mathrm{l})$ and $1 \mu \mathrm{l}$ sterile water to a final volume of $6 \mu \mathrm{l}$. The reaction was gently mixed and incubated for 5 min. at room temperature.

\section{Purification of the Recombinant His-tagged Subunits}

Induced bacterial cells were harvested by centrifugation at $5,000 \mathrm{~g}$ for $2 \mathrm{~min}$ at room temperature. $10 \mathrm{~mL}$ of lysisbuffer $(20 \mathrm{mM}$ Phosphate buffer ( $\mathrm{pH} 7.8$ ), $500 \mathrm{mM} \mathrm{NaCl} 2$ and $1 \mathrm{mM}$ PMSF) was added. Cells were suspended by vigorous vor texing. Lysozyme was added to a final concentration of $1 \mathrm{mg} / \mathrm{mL}$, mixed by gentle vortexingandkept on ice for $1 \mathrm{~h}$ with intermittent shaking. 1\% Triton X-100 was added and the mixture was further incubated for $30 \mathrm{~min}$. It was then centrifuged for $20 \mathrm{~min}$ at $14,000 \mathrm{~g}$ at $4^{\circ} \mathrm{C}$. Supernatant was collected (in case of thesoluble protein) and loaded on Ni- NTA matrix preequilibratedwith loading buffer (Buffer A, 20 mMPhosphate buffer (pH 7.8), $500 \mathrm{mMNaCl}$ ). Matrix was washed with 10 column volumes of loading buffer. Elution was carried out sequentially with 20 mMPhosphate buffer ( $\mathrm{pH}$ 6.0), 500 $\mathrm{mMNaCl}, 50$ mMimidazole (Buffer B) and 20 $\mathrm{mM}$ Phosphate buffer (pH6.0), $500 \mathrm{mMNaCl}$, $250 \mathrm{mM}$ imidazole (Buffer C). All thefractions were analyzed by resolving equal volumes ofeach on $13 \%$ SDS-PAGE. Also the absorbance at 280 $\mathrm{nm}$ was measured for all the fractions followed by measuring the immunoreactivity. Protein was estimated according toprotocol given by Bradford [36]. Proteins were essentially resolved by high resolution SDS-Polyacrylamide slab gel electrophoresis system [37].

Biological estimation of the activity of the prepared recombinant buffalo FSH in vivo:

Estimation of both FSH in vivo was carried out according to the method of Steelman and Pohly[38], briefly, $3 \mu \mathrm{g}$ recombinant buffalo FSH and different doses of PMSG (1-20 i.u.) were injected intraperitoneally for immature female rats (Ages less than 21 days)

All animals will be kept to a cage with ad libitum food and water, at a constant temperature $\left(22^{\circ} \mathrm{C}\right)$ and light cycle (12 hr light) during the experimental period.The animals were 
classified into the following groups:Group $1(n=5)$ : Treated with normal saline. Groups 2-5(n=5/group): Treated with 1,5,10 and 20 i.u. PMSG(FSH), respectively as a single dose (IP) and considered standard for different doses of pregnant mare serum gonadotropin (FSH).Group $6(\mathrm{n}=5)$ : treated with $3 \mu \mathrm{g}$ of the prepared recombinant buffalo $\mathrm{FSH}$ for 3 days.All animals were decapitated $24 \mathrm{hrs}$ post injection of injecting hormones (PMSG or rec. buff.FSH).

The genitalia and ovaries were weighted, the numbers of follicles, corpora hemorrhagica and corpora lutea were counted under stereomicroscope.

The ovaries and uteri were fixed in $10 \%$ formalin for histological examination.

\section{Results and Discussion}

Pituitary glands obtained within half an hour of slaughter were immediately subjected to RNA isolation following the classical protocol [34] . The yield was in range of $2.2-3 \mathrm{pg} / \mathrm{mg}$ of the pituitary. The quality of the RNA as assessed by the A260:A280 ratio was clear bands and of good quality.

A total of about $15 \mathrm{pg}$ of first strand cDNA was synthesized from a total of $3 \mathrm{pg}$ RNA. Further the different pair of primers (Fig 2) used gave a gene specific amplification. The PCR product when analyzed on a $1 \%$ agarose gel yielded different amplicons sizes as follows FSH $\beta$ 390bp, Gonadotropin $\alpha 127 \mathrm{bp}$, TSH $\beta 417$ bp and LH $\beta$ 426bp (Fig.1). Further PCR products were sequenced commercially using the specific primer to each gene. The sequenced genes were aligned to the other available sequences in the NCBI database of GenBank and there are very few differences in the coding sequences

Results are presented in Fig. 2 where agarose gel electrophoresis of PCR product demonstrated the amplification of LH and FSH genes to the expected molecular weight of each gene. The PCR product was successfully purified from gel using Qiaquick Gel Extraction Kit to be cloned later.

In Fig.3,where the white transformed bacterial colonies were observed within $24 \mathrm{hrs}$ indicating the transformation of the competent E. coli cells. The four genes obtained from PCR reaction $(a, b, c, d)$ were analyzed using sequencer (Table 3 ) and the results showed that the matching identity of these genes were with (FSH $\beta$, FSH $\alpha$, TSH $\beta$, LH $\beta$ ) genes, respectively.

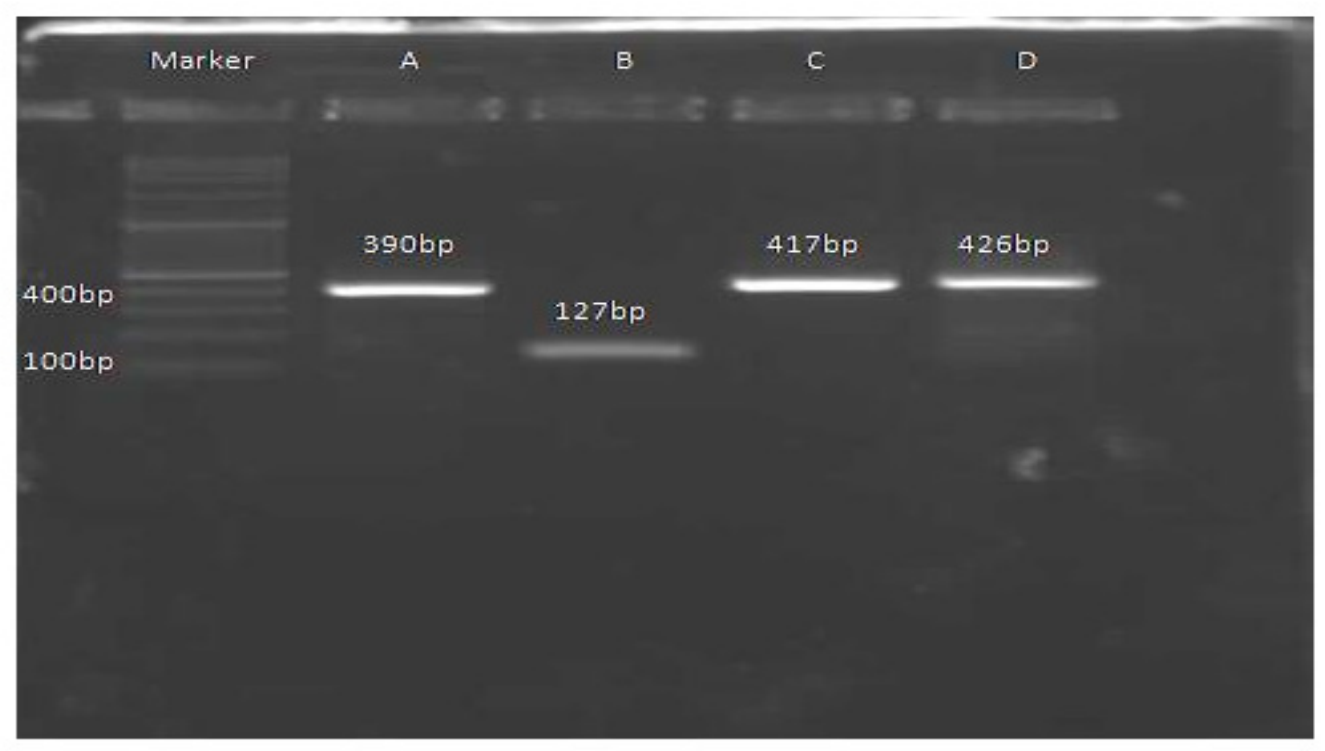

Fig. 1. This figure shows PCR amplified products of different genes from buffalo pituitary first strand $\mathrm{c}$ DNA of FSH beta 390 bp (A), Gonadotropin alpha subunit (B), TSH beta 417 bp (C) And LH beta (D) . A 100 bp DNA Marker is loaded along with to ascertain the exact size. 


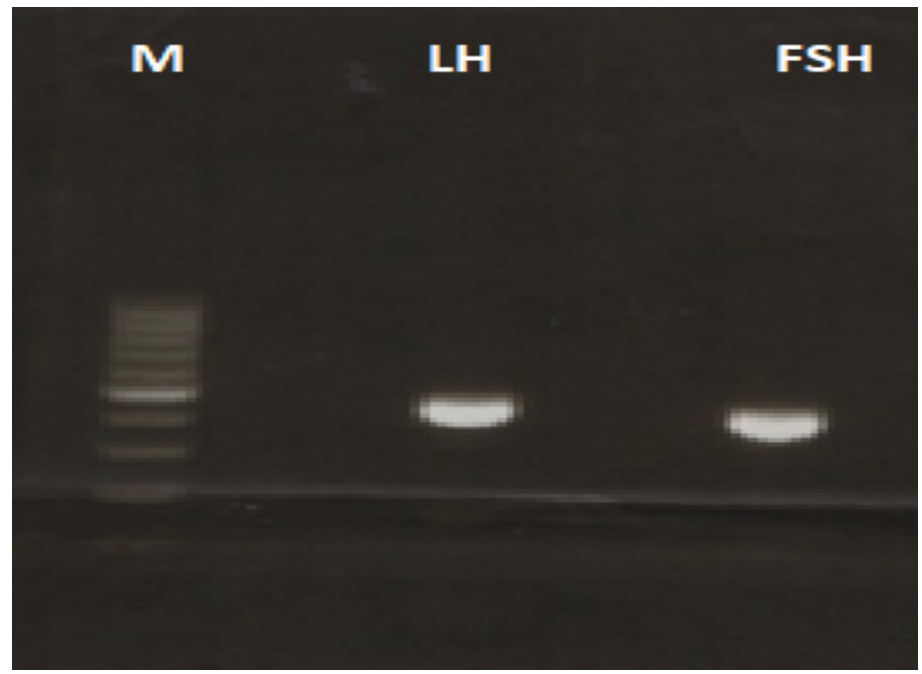

Fig. 2. Agarose gel electrophoresis showing the amplification the target genes by RT-PCR. Lane (M): 100 bp DNA Ladder.
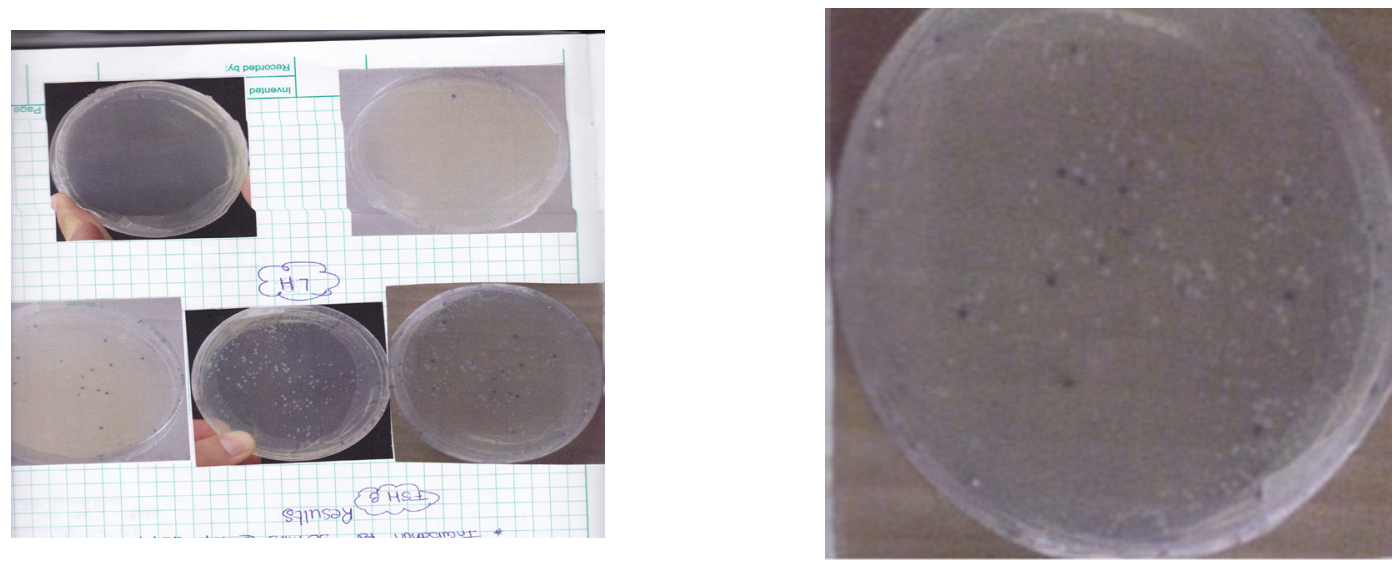

Fig. 3\&4. Transformed bacterial colonies on LB agar plate with ampicillin and X-gal for selection. White colonies represent the transformed $\mathrm{E}$. coli cells by the $\mathrm{pCR2.1-TOPO/LH}$ and $\mathrm{pCR2.1-TOPO/FSH} \mathrm{constructs}$ while the blue colonies represent the transformation by vector molecule without insert.

TABLE 4. Showing matching identity of four gene sequences $(a, b, c, d)$ with genes from NCBI database

\begin{tabular}{cclc}
\hline Name & Length & \multicolumn{1}{c}{ Gene } & $\begin{array}{c}\text { Identity } \\
\text { matching }\end{array}$ \\
\hline a_1 & 371 & Bubalusbubalisfollitropin subunit beta-like (FSH), mRNA & $98 \%$ \\
a_2 & 370 & Bubalusbubalisfollitropin subunit beta-like (FSH), mRNA & $99 \%$ \\
b_3 & 103 & Bubalusbubalisfollitropin subunit alph-like (FSH), mRNA & $97 \%$ \\
b_4 & 109 & Bubalusbubalisfollitropin subunit alph-like (FSH), mRNA & $99 \%$ \\
c_5 & 390 & Bubalusbubalis thyroid stimulating hormone, beta (TSHB), mRNA & $99 \%$ \\
c_6 & 399 & Bubalusbubalis thyroid stimulating hormone, beta (TSHB), mRNA & $99 \%$ \\
d_7 & 407 & Bubalusbubalis luteinizing hormone beta polypeptide (LHB), mRNA & $100 \%$ \\
d_8 & 405 & Bubalusbubalis luteinizing hormone beta polypeptide (LHB), mRNA & $99 \%$ \\
\hline
\end{tabular}

Concentration of the purified fragment was determined using NanoDrop (Thermo Fisher Scientific, USA) .

The results showed the 65 and $85 \mathrm{ng} / \mu 1$ of LH and FSH, respectively. 


\section{TA cloning of LH and FSH genes}

The different PCR products were cloned in pGEMT Easy vector. The E.coli component cells were efficiently transformed and about $85 \%$ of white colonies were obtained .The transformation was observed as shown in Fig. 3 in which the white transformed bacterial colonies were observed within 24 hrs indicating the transformation of the competent $E$. coli cells.
The recombinant plasmids were purified from nine white colonies of $\mathrm{E}$. coli using miniprep protocol as described in methods [38]. Isolated plasmids DNA from these transformed bacteria were then detected by $1 \%$ agarose gel electrophoresis as shown in Fig 5. Samples naming 1, 2, 4, 6 and 9 were recorded as positive samples having higher molecular weights) than the negative samples.

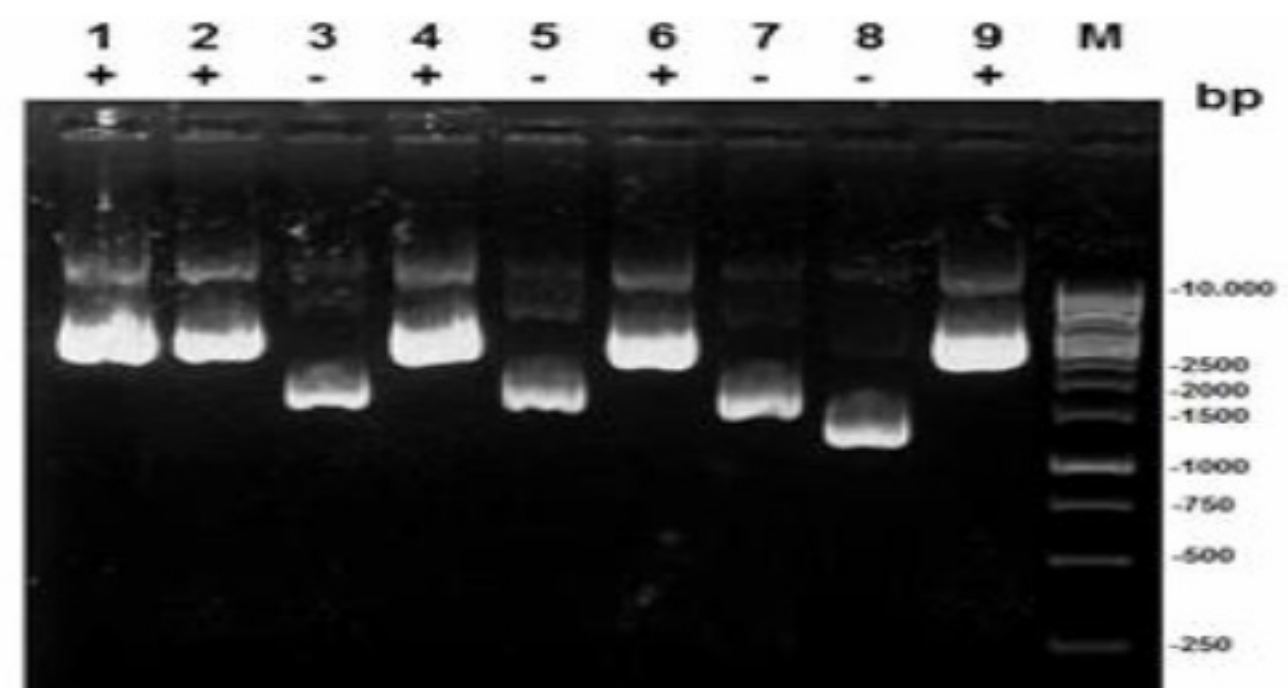

Fig. 5. Electrophoretic analysis of the constructed plasmids after isolation by miniprep protocol. Lanes (1:9): the isolated plasmids from nine white colonies. Lane (M): 1kbp DNA Ladder. As appear, lanes 1, 2, 4, 6 and 9 represent the positive samples having higher molecular weights, of plasmid plus the inserted fragment, than the negative samples.

In the present work the obtained cDNAs from buffalo pituitaries was corresponding to the buffalo pituitary glycoprotein hormonal subunits have been cloned and expressed, and sequence was submitted to GenBank. The cDNA and the expressed protein for different subunits of bubaline glycoprotein hormones (FSH,LH, TSH and glycoprotein) into E.coli had the expected composition of the nucleotides and amino acids . The different beta subunits also have a varied similarity at the level of cDNA sequences and the deduced amino acid sequences. At the cDNAlevel the general similarity is ranged from 97 to $100 \%$ for the various alpha and beta subunits. That the glycoprotein hormonal subunits were well conserved sequences across the species is well accepted $[39,40]$. The beta subunits of the glycoprotein hormones have been reported to be expressed at a very lower level in E. coli because of a self-attenuating region in the 5 sequence of the mRNA. The expression of the N-terminal gelation constructs of the bFSH $\beta$ have been shown to increase in this case [41].
Biological activity of recBuff.FSH.

Estimation of biological activity of recombinant buffalo FSH as compared with standard doses of pregnant mare serum gonadotropin(PMSG, 1-20 i.u.).

-Estimation of FSH-like activity of the prepared rec.buff FSH in immature female rats

As shown in the Figures (9a-c), the recombinant buffalo FSH possess high biological activity in immature female rats as compared with negative control (Fig.6a,b) and positive control (given different doses of PMSG as shown in Figs.7a,b \& 8a,b). The activity of recBuffalo FSH in experimental rats was an increase in the volume and weight of genitalia(not shown here), enlargement and thinning of uterine horns and filled with large quantities of uterine secretion. The ovaries are large in size containing a high numbers of growing follicles at different developmental stages particularly Graffianfollicles .The present work proved that the prepared recombinant follicle stimulating hormone from pituitaries of buffaloes posse a high biological activity as estimated in experimental immature female rats in vivo. 

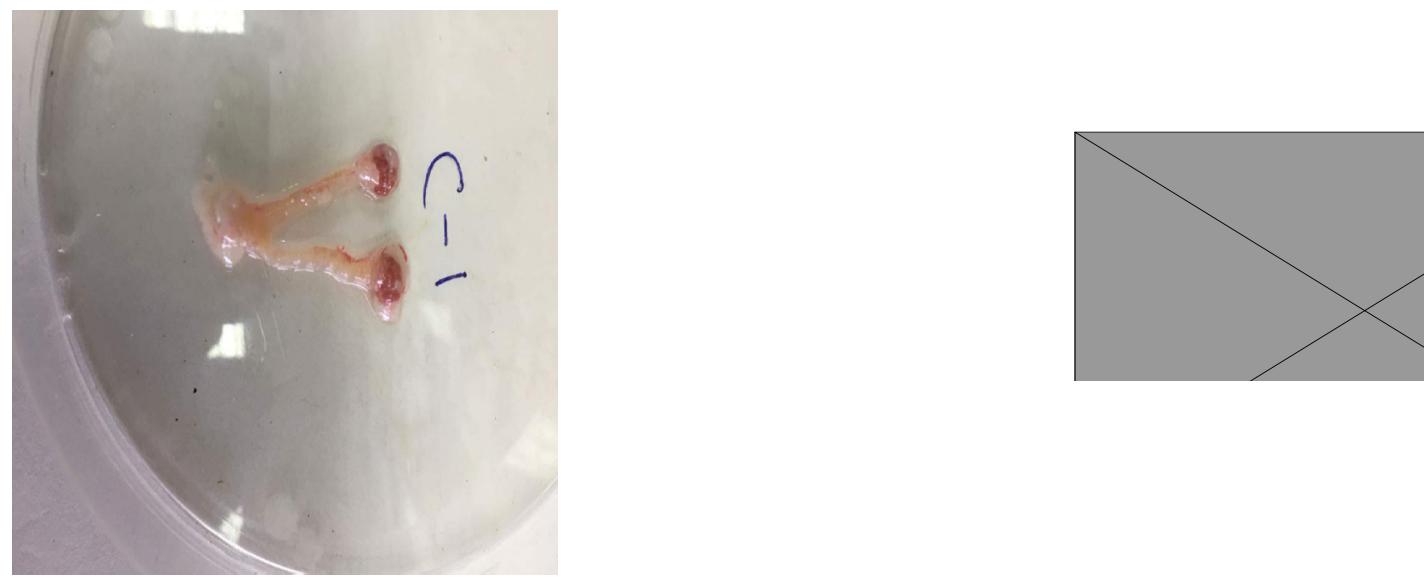

Fig.(6a,b). Immature female rats treated IP with saline (-ve Control group), the ovaries contain scanty numbers of follicles, the uterine horns filled with scanty uterine secretions and the wall of uterus and uterine horns are tick and short in length.
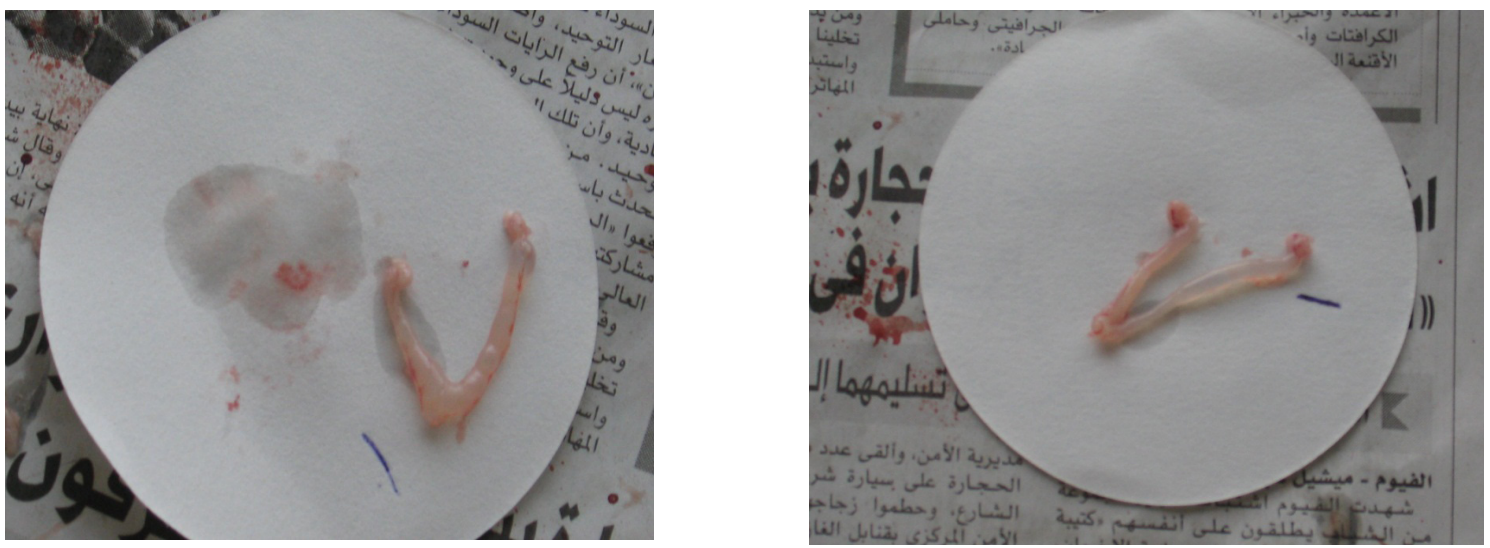

Fig.(7a,b).Immature female rats treated with 1 i.u. PMSG IP, single injection, the uterine horns are thin, filled with huge amounts of uterine fluids,and the ovaries containing large numbers of follicles at different developmental stages.
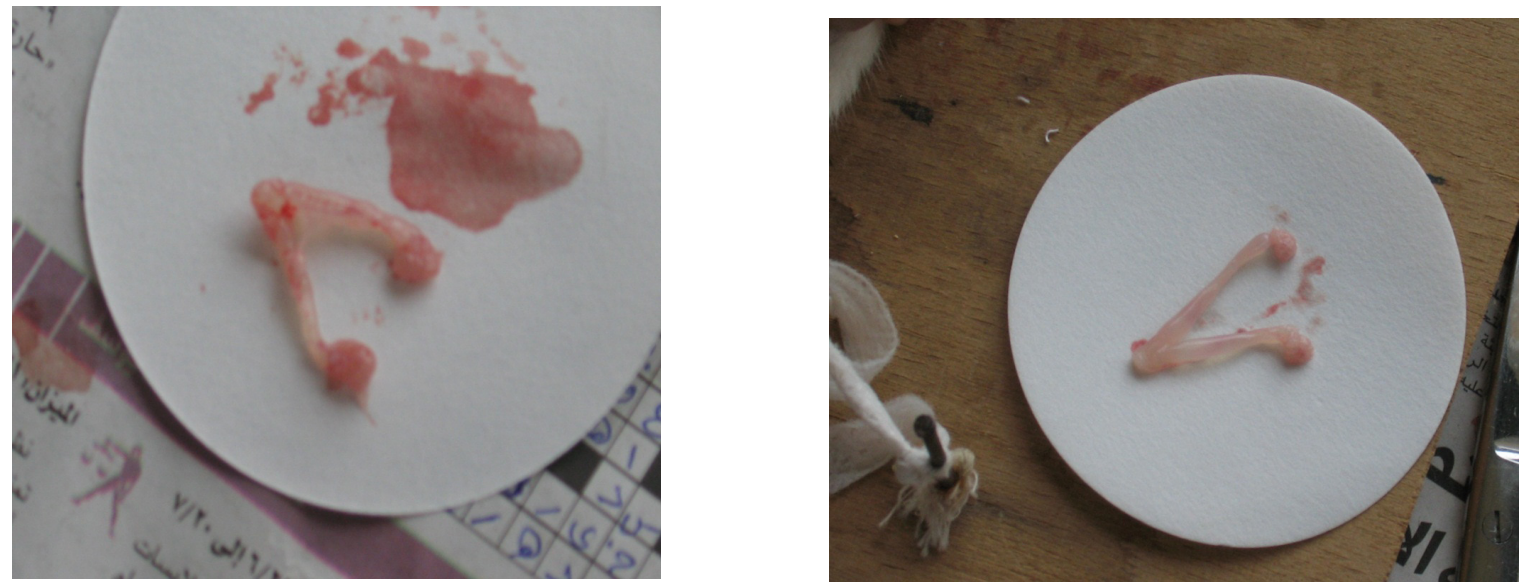

Fig.(8a,b). Immature female rats treated with 20 i.u. PMSG IP, the ovaries are enlarged containing huge numbers of large and growing follicles, the uterine horns are filled with large amounts of uterine fluids. The uterine horns are short and the uterine wall is thin 

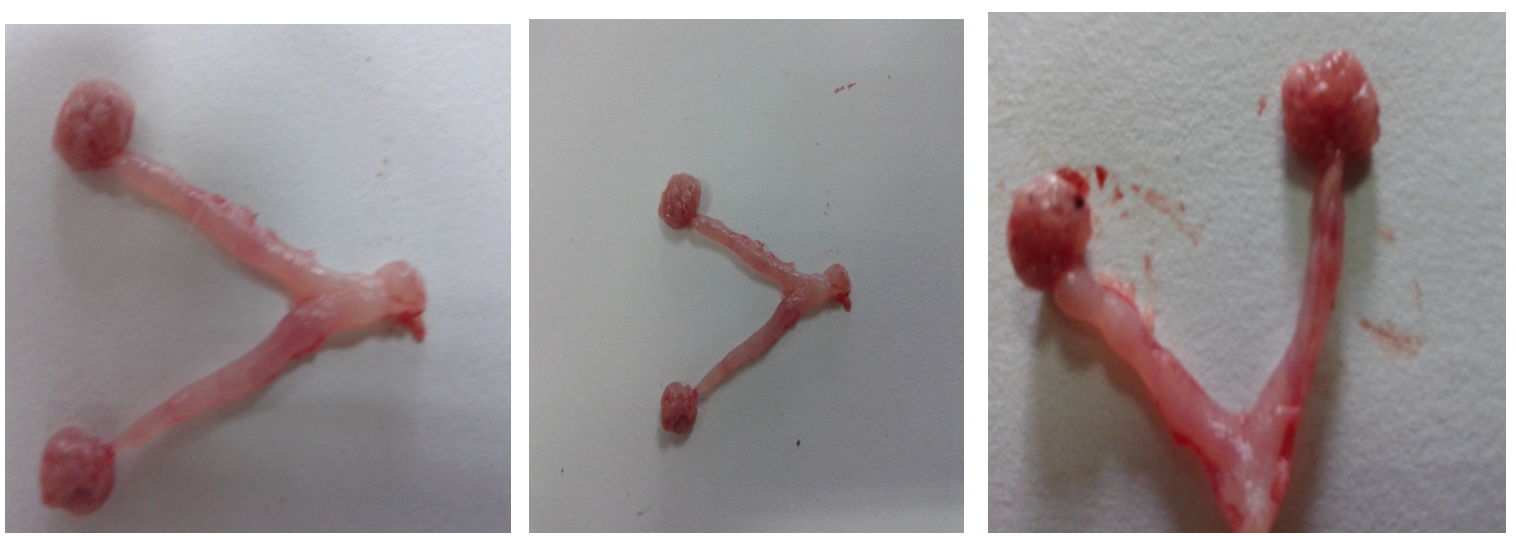

Fig.(9a-c). Immature female rats treated with 5 ug recombinant buffalo FSH injected IP, the ovaries are enlarged containing huge sever numbers of large and growing follicles, the uterine horns are filled with medium amounts of uterine fluids. The uterine horns are short and the uterine wall is thin .

Acknowledgements: The present work was supportedfinancially by the funds from STDF (Project no. 6889). The authors would like to thank Dr. Haggag Salah Zain, Biotechnology Centre, Faculty of Agriculture, Cairo university for extraction and isolation of cDNA.

\section{Conflict of interest \\ No conflict of interests}

\section{$\underline{\text { References }}$}

1. FAO: Food and Agriculture Organization, Year Book of production, United Nation (2005).

2. FAO: Food and Agriculture Organization, Year Book of production, United Nation (2010).

3. Ahmed, S., Mahrous, K. and EI-Sobhy, H. Cytogenetic study of buffalo under pollution of environmental conditions. Mutat. Res., 419, 2126(1998)

4. Sharma, K., Dutta, N., Pattanaik, A.K. and Hasan, Q.Z. Replacement value of undecorticated sunflower meal as a supplement for milk production by crossbred cows and buffaloes in the northern plains ofIndia. Trop. Anim. Health Prod., 35, 131-145 (2003).

5. Arya, J.S. and Madan, M. Postpartum reproductive cyclicity based on ovarian steroids in suckled and weaned buffaloes. Buff. J., 17, 361-369 (2001).

6. Ashwani, S.K.,Parkash, B.S.,Amarjit, N.S. and Bukkarao, P.S. Effect of suckling on basal and GnRH-induced LH release in post-partum dairy buffaloes. Anim. Reprod.Sci., 95 (3-4), 244-250 (2006).
7. El-Wishy, A.B. The postpartum buffalo II.Acyclicity and anestrus .Animal Reprod. Sci., 97, 216-236( 2007).

8. Drost, M. Advanced reproductive technology in the water buffalo. Theriogenol.,68, 450-453(2007).

9. Gasparrini, B. In vitro embryo production in buffalo species: state of theart.Theriogenol., $\mathbf{5 7}$ 237-242 (2001).

10. Galli, C., Duchi, R., Crotti, G., Turini, P., Ponderato, N., Colleoni, S., Lagutina, I. and Lazzari, G.Bovine embryo technologies. Theriogenol., 59, 599-616 (2003).

11. Adams, T.E. and Boime, I. The expanding role of recombinant gonadotropins in assisted reproduction. Reprod. Domest.Anim., 43, 186-192 (2008).

12. Kanitz, W., Becker, F., Schneider, F., Kanitz, E., Leiding, C., Nohner, H. and Pohland, R.Superovulation in cattle: practical aspects of gonadotropin treatment and insemination. Reprod. Nutr.Dev., 42, 587-599 (2002).

13. Keene, J.L., Matzuk, M.M., Otani, T., Fauser, B.C.J.M., Galway, A.B., Hsueh, A.J.W. and Boime, I. Expression of biologically active human follitropin in Chinese hamster ovary cells. J. Biol. Chem., 264, 4769-4775 (1989).

14. D’ Antonio, M., Borrelli, F., Datola, A., Bucci, R, Mascia, M., Polletta, P., Piscitelli, D. and Papoian $\mathrm{R}$ Biological characterization of recombinant human folliclestimulating hormone isoforms. Hum. Reprod., 14, 1160-1167(1999). 
15. Perlman, S., van den Hazel, B., Christiansen, J., Gram-Nielsen, S., Jeppesen C.B., Andersen, K.V., Halkier, T., Okkels, S. and Schambye, H.T. Glycosylationof an N-terminal extension prolongs the half-life and increases the in vivo activity offollicle stimulating hormone. J. Clin. Endocrinol.Metab., 88, 3227-3235 (2003).

16. Trousdale, R.K., Yu B., Pollak, S.V., Husami, N., Vidali, A. and Lustbader, J.W. Efficacy of native and hyperglycosylated follicle-stimulating hormone analogs for promoting fertility in female mice. Fertil.Steril., 91, 265-270 (2009).

17. Devroey, P., Fauser, B.C., Platte au, P., Beckers, N.G., Dhont, M. and Mannaerts, B.M. Induction of multiple follicular development by a single dose oflong-acting recombinant follicle-stimulating hormone (FSH-CTP, corifollitropinalfa) forcontrolled ovarian stimulation before in vitro fertilization. JClin. Endocrinol. Metab., 89, 20622070 (2004).

18. Fauser, B.C., Mannaerts, B.M., Devroey, P., Leader, A., Boime, I. and Baird, D. T. Advances in recombinant DNA technology: corifollitropinalfa, a hybrid molecule with sustained folliclestimulating activity and reduced injection frequency. Hum. Reprod. Update, 15, 309-321 (2009).

19. Garcia-Campayo, V., Jablonka-Shariff, A. and Boime, I. A single-chain bifunctional gonadotropin analog is secreted from Chinese hamster ovary cells as two distinct bioactive species. J. BioI. Chern., 279, 44286-44293 (2004).

20. Wilson, J.M., Jones, A.L., Moore, K., Looney,c.R. and Bondioli, K.R.Superovulation of cattle with a recombinant-DNA bovine follicle stimulating hormone. Anim. Reprod.Sci., 33,71-82 (1993).

21. Wilson, M.E., Morris, J.e., and Gibbons, J.R. Bioactive, bacterial-derived recombinant bovine follicle stimulating hormone. Proceedings of the $34^{\text {th }}$ Annual Conference of the International Embryo Transfer Society, Orlando, FL.(2009).

22. Hesser, M.W. A survey of heterologous expression systems for the production of bovine follicle stimulating hormone and luteinizing hormone. Ph.D. Thesis, Clemson University (2011).

23. Chappel, S., Looney, C.R and Bondioli, K.R Bovine FSH produced by recombinant DNA technology. TheriogenoI., 29, 235 (1988).

24. Zmora N., Kazeto Y., Kumar R.S., Schulz R.W. and Trant J.M. Production of recombinant channel catfish (Ictaluruspunctatus) FSH and LH in S2 Drosophila cell. Journal of Endocrinology, 194, 407-416 (2007).

25. [25]. Kazeto, Y., Kohara, M., Miura, T., Miura, c., Yamaguchi, S., Trant, J.M., Adachi, S. and Yamauchi, K. Japanese eel follicle-stimulating hormone (FSH) and luteinizing hormone (LH): production of biologically active recombinant FSH and LH by Drosophila S2 cells and their differential actions on the reproductive biology. BioI.Reprod ., 79, 938-946 (2008).

26. Dirnberger, D., Steinkellner, H., Abdennebi, L., Remy, J.J. and van de Wiel, D. Secretion of biologically active glycoforms of bovine follicle stimulating hormone in plants. Eur. 1.Biochem.,268, 4570-4579(2001).

27. Kasuto, H. and Levavi-Sivan, B. Production of biologically active tethered tilapia LH a by the methylotrophic yeast Pichiapastoris. Gen. Compo Endocrinol., 140, 222-232 (2005).

28. Chen, J., Zhang, Y., Tang, Z., Mao, J.,Kuang, Z., Qin, C. and Li, W. Production of recombinant orange-spotted grouper (Epinepheluscoioides) follicle-stimulatinghormone (FSH) in singlechain form and dimer form by Pichiapastoris and theirbiological activities. Gen. Compo Endocrinol., 178,237-249 (2012).

29. Galet,C., Le Bourhis, C.M., Chopineau, M., Le Griec, G., Perrin, A., Magallon, T., Attal, J., Viglietta, C.,Houdebine, L.M. and Guillou, F.Expression of a single 13achain protein of equine LH/CGin milk of transgenic rabbits and its biologicalactivity. Mol Cell.Endocinol., 174, 31-40 (2001).

30. Coulibaly, S., Besenfelder, u., Miller, I., Zinovieva, N., Lassnig, C., Kotler, T., Jameson, J.L.,Gemeiner, M., Muller, M. and Brem, G. Expression and characterization of functional recombinant bovine follicle-stimulating hormone (boFSHalP) producedin the milk of transgenic rabbits. Mol. Reprod. Dev., 63, 300-308 (2002).

31. Porro, D., Sauer, M., Branduardi, P. and Mattanovich, D. (2005) Recombinant protein production in yeasts. Mol. Biotechnol., 31, 245 259.

32. Wilson M., Morris J. and Gibbons J. Bovine and equine recombinant follicle stimulating hormone produced in two heterologus hosts: Escherichia Coli and Trypanosome Brucei. Reprod. Fert.Dev., 18, 241 - 242 (2006). 
33. Revelli, A.,Poso, F.,Gennarelli, G.,Moffa, F.,Grassi, G. and Massobrio, M. Recombinant versus highly-purified, urinary follicle-stimulating hormone (r-FSH vs. HP-uFSH) in ovulation induction: a prospective, randomized study with costminimization analysis. Reprod. Bio. Endocrinol., 4, 38 (2006).

34. Sambrook, J., Russel, G., Fritsch, E.F., Maniatis, T. Molecular Cloning. A Laboratory Manual, 2001,edn2. New York: Cold Spring Harbor Laboratory Press.

35. Nolan, T., Hands, R.E., Bustin, S.A.Quantification of mRNA using real-time RT-PCR. Nat. Protoc., 1 (3), 1559-82 (2006).

36. Bradford. M.M. "Rapid and sensitive method for thequantitation of microgram quantities of proteinutilizing the principle of protein-dye binding”, Anal.Biochem., 72, 248-54 (1976).

37. Laemmli, U.K. Cleavage of structural proteinsduring the assembly of the head of bacteriophaseT4. Nature.,227, 680-685 (1970).

38. Steelman, S.L. and Pohly,F.M.(1953) Assay of the follicle stimulating hormone based on the augmentation with human chorionic gonadotropin. Endocrinology, 53, 604.
39. Maniatis T., Fritsch E.F., Sambrook J. Molecular Cloning : A Laboratory Manual. Cold Spring Harbor, N.Y. : Cold Spring Harbor Laboratory (1982).Bookmark: https://trove.nla.gov.au/ version/40399603 (1982).

40. Pierce JG, Parson TF. Glycoprotein hormones: Structural and function. Ann. Rev. Biochem., 50, 465-495(1981).

41. NidhiVashistha, ManojPanchal, RajanDighe, KambadurMuralidhar. Buffalo pituitary gonadotropins: Characterization of bacterially expressed recombinant Alpha and hormone specific Beta subunits .World $J$ life Sci. and Medical Research, 3 (1),1-7 (2013)

42. Samanddar, M, Catterall, JF, Dighe, RR. Expression of biologically active Beta subunit of bovine follicle stimulating hormone in the methylotrophic yeast Pichiapastoris .Protein Expr. Purif., 10 (3), 345-355 (1997).

(Received 24/06/2018, accepted 04/07/2018) 
تحضير هرمون تحفيز الجريبات المركب للجاموس(rbuFSH) والفعال حيويا من الغدد

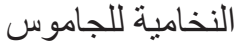

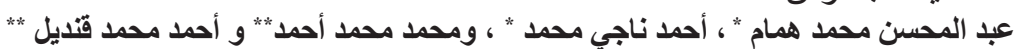

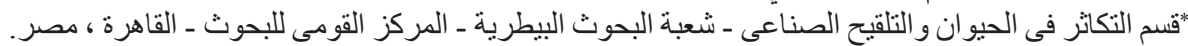
و،*قسم تلوث المياه ـ شعبة بحوث البيئة ـ المركز القومى للبحوث البحث ـ القاهرة ـ مصر.

بسبب الاختلافات المناعية في الوحدات الفرعية لهرمون تحفيز الجريبات_بيتا بين الحيو انات المختلفة والحاجة

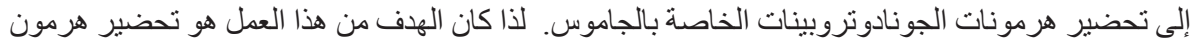

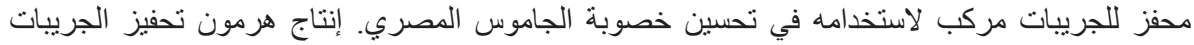

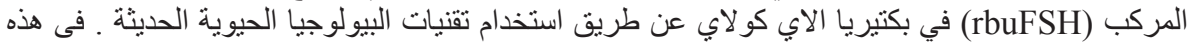

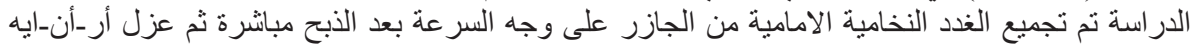

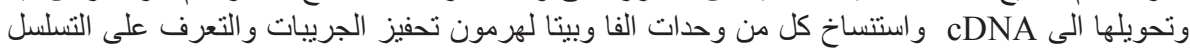

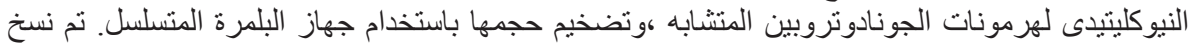

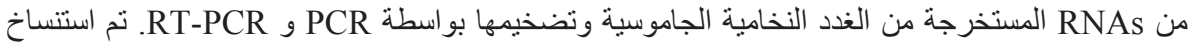

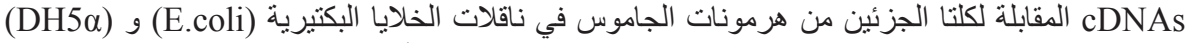

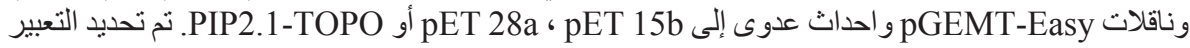

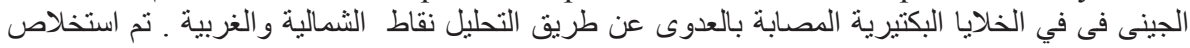

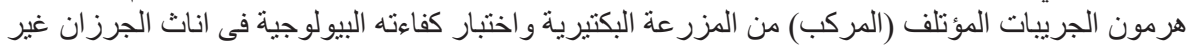

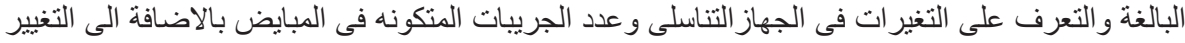

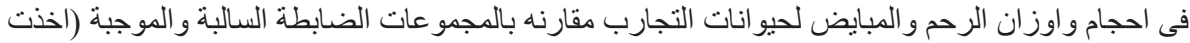

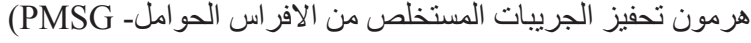

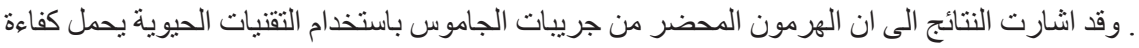

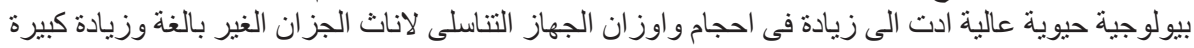

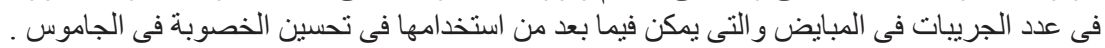

الكلمات الدالة FSH المؤتلف ، الجاموس ، الغدد النخامية ، cDNA ، الاستنساخ ، RT-PCR. 